\title{
Single nucleotide polymorphism of bone morphogenetic protein 4 gene: A risk factor of non-syndromic cleft lip with or without palate
}

\author{
Sathyaprasad Savitha, S. M. Sharma1', Shetty Veena², R. Rekha ${ }^{3}$ \\ Department of Pediatric Dentistry, KVG Dental College, 'Department of Oral and Maxillofacial Surgery, AB Shetty Dental College, \\ ${ }^{2}$ Department of Microbiology, KSHEMA, Mangalore, ${ }^{3}$ Department of Community Medicine, KVG Medical College, Sullia, D.K, \\ Karnataka, India
}

Address for correspondence: Dr. Savitha Sathyaprasad, Department of Pediatric Dentistry, KVG Dental College and Hospital, Sullia, D.K, Karnataka, India. E-mail: drsavithaks@yahoo.com

\section{ABSTRACT}

Background: The bone morphogenetic protein (BMP) signalling pathway is crucial in a number of developmental processes and is critical in the formation of variety of craniofacial elements including cranial neural crest, facial primordium, tooth, lip and palate. It is an important mediator in regulation of lip and palate fusion, cartilage and bone formation. Aim: To study the role of mutation of BMP4 genes in the aetiology of non-syndromic cleft lip with or without palate $(\mathrm{NSCL} \pm P)$ and identify it directly from human analyses. Materials and Methods: A case-control study was done to evaluate whether BMP4T538C polymorphism, resulting in an amino acid change of Val=Ala (V152A) in the polypeptide, is associated with NSCL $\pm P$ in an Indian paediatric population. Genotypes of 100 patients with NSCL $\pm P$ and 100 controls (in whom absence of $\mathrm{CL} \pm P$ was confirmed in three generations) were detected using a polymerase chain reaction-restriction fragment length polymorphism strategy. Logistic regression was performed to evaluate allele and genotype association with NSCLP. Results: Results showed significant association between homozygous $\mathrm{CC}$ genotype with $\mathrm{CL} \pm P$ (odds ratio [OR]-5.59 and $95 \%$ confidence interval $[\mathrm{Cl}]$ $=2.85-10.99$ ). The $538 \mathrm{C}$ allele carriers showed an increased risk of NSCL $\pm P$ as compared with $538 \mathrm{~T}$ allele (OR - $4.2 \% \mathrm{Cl}=2.75-6.41)$. Conclusion: This study suggests an association between SNP of BMP4 gene among carriers of the $\mathrm{C}$ allele and increased risk for NSCLP in an Indian Population. Further studies on this aspect can scale large heights in preventive strategies for NSCLP that may soon become a reality.

\section{KEY WORDS}

Aetiology of non-syndromic cleft lip and palate; bone morphogenetic protein 4 gene; bone morphogenetic protein gene

\begin{tabular}{|l|l|}
\hline \multicolumn{2}{|c|}{ Access this article online } \\
\hline Quick Response Code: & Website: \\
\hline & www.ijps.org \\
\hline & Dol: \\
\hline
\end{tabular}

This is an open access article distributed under the terms of the Creative Commons Attribution-NonCommercial-ShareAlike 3.0 License, which allows others to remix, tweak, and build upon the work non-commercially, as long as the author is credited and the new creations are licensed under the identical terms.

For reprints contact: reprints@medknow.com

How to cite this article: Savitha S, Sharma SM, Veena S, Rekha $\mathrm{R}$. Single nucleotide polymorphism of bone morphogenetic protein 4 gene: A risk factor of non-syndromic cleft lip with or without palate. Indian J Plast Surg 2015;48:159-64. 


\section{INTRODUCTION}

he formation of mammalian palate is a multistep process coordinated by a network of transcription factors and signalling molecules together with proteins conferring cell polarity and cell - cell interactions that includes palatal shelf growth, elevation of shelves, fusion between paired shelves and the disappearance of midline epithelial seam, ${ }^{[1]}$ which degenerates by apoptosis; and the fusion is complete. ${ }^{[2,3]}$ Moreover, ossification occurs in the anterior two-third of the palate and form the hard palate. ${ }^{[4]}$ Disturbance of this tightly controlled cascade can result in a facial cleft when the facial primordia fail to meet and fuse. Recent successes in genome-wide linkage and association studies have identified novel loci significantly associated with $\mathrm{CLP}^{[5-9]}$ Several genes have been proposed based on the understanding of the molecular and cellular processes that orchestrate morphogenesis of the midface. The use of mouse models and modern molecular techniques have greatly facilitated the process of craniofacial research and extended our understanding of craniofacial development in the past decade. The bone morphogenetic protein (BMP) signalling pathway has been shown to be involved in a number of developmental processes and critical in the formation of variety of craniofacial elements including cranial neural crest, facial primordial, tooth, lip and palate. ${ }^{[10]}$ BMP-regulated genes control self-renewal, osteoblast differentiation and negative feedback regulation, suggesting that BMP signalling regulates facial skeletal morphogenesis by controlling the balance between self-renewing progenitors and differentiating lineage-restricted cells, is an important mediator in the process of orofacial union is indicated by Alk deficient mice, in which orofacial clefts is shown. ${ }^{[10]}$ BMP4 is highly expressed in the putative orofacial epithelia prior to the facial union. ${ }^{[11]}$ A recently generated mouse model with inactivation of BMP4 from facial primordial showed delay of Fgf8, a critical gene for early facial development, which fails to be unregulated at a crucial developmental stage and results in cleft lips. BMP4 expression localises at the site of fusion of the mice facial prominences. ${ }^{[11]}$ The conditional inactivation of BMP4 in a transgenic mice line results in an isolated cleft lip confirms a role in lip fusion. Several BMP genes including BMP2, BMP4 and BMP7 are expressed in developing mouse palatal shelves. ${ }^{[12]}$ The importance of BMP4 signalling in palate development was also demonstrated in Msx 1 mutant mouse, which exhibits cleft palate phenotype. ${ }^{[13]}$ Msx 1 was required for the expression of BMP4 and BMP2 in the palatal mesenchyme and sonic hedge hog $(\mathrm{SHH})$ in the medial edge epithelium. BMP4 appears to bypass a requirement for Msx 1 and to function upstream of $\mathrm{SHH}$ and BMP2 to regulate palate development. ${ }^{[14]}$ Inactivation of BMP4 - BMPr1a genetic pathway by Nestin-Cre transgenic line mutant mice demonstrated orofacial clefting, thus, revealing the role of BMP signalling in the orofacial union. ${ }^{[15]}$ Authors demonstrated that the BMP4/ BMPrla pathway was critical for the lip development. ${ }^{[16]}$ BMPr1a gene, encoding a type I receptor for BMPs is preferentially expressed in the primary palate and anterior secondary palate during palatal outgrowth, tissuespecific inactivation of BMPr1a in the developing palatal mesenchyme in mice cause reduced cell proliferation in the primary and anterior secondary palate, resulting in partial cleft of the anterior palate at birth. The expression of Msx1, Fgf10 and SHH was down-regulated in the anterior palate mesenchyme indicating that BMP signalling regulates mesenchymal-epithelial interactions during palatal outgrowth. In addition, the formation of the palatal processes of the maxilla was blocked while the formation of the palatal processes of the palatine was significantly delayed; resulting in the submucous cleft of the hard palate. BMP signalling also plays critical roles in the regulation of palatal mesenchyme condensation and osteoblast differentiation during palatal bone formation. Hence, BMP4 is considered a promising candidate gene and is intensely studied in association studies using casecontrol ${ }^{[16,17]}$ and case-parent trio designs. ${ }^{[18-20]}$ The present case-control study was undertaken to evaluate whether BMP4T538C polymorphism, resulting in an amino acid change of valine to Alanine is associated with nonsyndromic cleft lip with or without cleft palate (NSCLP) in a Indian population so that knowledge regarding the risk factor should eventually result in improved prevention, treatment and prognosis for individuals with these conditions.

\section{MATERIALS AND METHODS}

Our sample consisted of 200 individuals; case group composed of 100 individuals with NSCLP (52 males and 48 females) belonging to age group of 6 months to 18 years old enrolled for various rehabilitation procedures in cleft lip and palate centres. Subjects were recruited between 2010 and 2012 from the centres of research involved in Craniofacial Project in Karnataka, India. The morphological nature of our study group was cleft lip with or without palate including both unilateral and 
bilateral cleft, but not associated with any syndromes and no family history of clefts or neural crest cell disorders. All cases selected using the same clinical protocol, including family history. Control group were recruited from 100 phenotypically normal unrelated individuals reporting to the same hospital for treatment of trauma or other injuries they were age and gender matched (54 males and 46 females) confirming absence of family history of absence of oral cleft in three generations, also malformations of neural tube defects, monogenic twins and children with syndromes were excluded. The study was approved by the local Institutional Review Boards. All participants provided informed consent. The informed consent for patients under 18 years old was obtained from their parents.

Polymerase chain reaction-restriction fragment length polymorphism (PCR-RFLP) was done after DNA extraction; genomic DNA was extracted from ethylenediaminetetraacetic acid peripheral blood leucocytes by HiMedia blood DNA extraction kit. Briefly, $200 \mu \mathrm{l}$ blood samples were taken into the microcentrifuge tube, and $20 \mu \mathrm{l}$ protease was added. Then, $200 \mu \mathrm{l}$ buffer $\mathrm{AL}$ was added to the tube and mixed by pulse-vortexing for $15 \mathrm{~s}$ and then incubated at $56^{\circ} \mathrm{C}$ for $10-20 \mathrm{~min}$. Two hundred microlitres ethanol was added to the microcentrifuge tube and mixed transferred to mini spin column placed in a $2 \mathrm{ml}$ collection tube and centrifuge at $8000 \mathrm{rpm}$ for $1 \mathrm{~min}$. The flow through was discarded after centrifugation at $6000 \times \mathrm{g}$ for $1 \mathrm{~min}$, the bound DNA was washed by adding $500 \mu \mathrm{l}$ buffer AW1 followed by centrifugation at $6000 \times \mathrm{g}$ for $1 \mathrm{~min}$. Then, flow through was discarded, and $500 \mu \mathrm{l}$ buffer AW2 was added and centrifuged at $2000 \times g$ for $3 \mathrm{~min}$. The DNA was eluted by adding $100 \mu \mathrm{l}$ buffer $\mathrm{AE}$ to the mini spin column placed in a fresh microcentrifuge tube and collected by centrifuging the column at $6000 \times \mathrm{g}$ for $1 \mathrm{~min}$. The extracted DNA was stored at $-20^{\circ} \mathrm{C}$ till further use. The standardisation of PCR condition for BMP4F/R primer was done in a programmable gradient thermocycler. Polymerisation chain reaction was carried out in $50 \mu \mathrm{l}$ reaction mixture containing $5.0 \mu \mathrm{l}$ of template DNA, $\times 1$ assay buffer, 100 $\mu \mathrm{M}$ of each of the four dNTP's, 10 picomoles of forwards and reverse primers and $1.25 \mathrm{U}$ of Taq DNA polymerase PCR was performed using a thermocycler. The primer sequences used were BMP4F-5'CCTAACTGTGCCTAG3' and BMP4R-5'CATAACCTCATAAATGTTTATACGG3'. The optimised PCR programme consisted of an initial denaturation step at $94^{\circ} \mathrm{C}$ for $12 \mathrm{~min}$ followed by 35 cycles of $1 \mathrm{~min}$ at $94^{\circ} \mathrm{C} ; 1 \mathrm{~min}$ at $54^{\circ} \mathrm{C} ; 1 \mathrm{~min}$ at $72^{\circ} \mathrm{C}$ and a final elongation at $72^{\circ} \mathrm{C}$ for $10 \mathrm{~min}$. The PCR products were detected by agarose gel electrophoresis. About 2.5\% agarose gels were prepared in $\times 1 \mathrm{TAE}$ buffer. The molten agarose was cooled to below $65^{\circ} \mathrm{C}$, ethidium bromide was added to a final concentration of $0.5 \mu \mathrm{g} /$ $\mathrm{ml}$ mixed and poured to gel mould and allowed to set. Ten microlitres of the PCR products were mixed with $4 \mu \mathrm{l}$ of $\times 6$ loading buffer and loaded into the wells in agarose gel. Gene Ruler 50 bp DNA ladder was used as a molecular weight marker. Electrophoresis was carried out at $100-120 \mathrm{~V}$ resolved on $2.5 \%$ agarose gels and visualised under ultraviolet transilluminator [Figure 1]. The blood DNA samples were used to amplify desired fragments of the BMP4 gene by PCR, using BMP4F/R primers. Restriction digestion; the PCR products were digested with $H p h I$ for $3-4 \mathrm{~h}$ at $37^{\circ} \mathrm{C}$ and inactivated by increasing temperature to $80^{\circ} \mathrm{C}$ for $20 \mathrm{~min}$. The digested PCR products after standardisation of PCR conditions, the optimum annealing temperature was selected and used for further amplification. The BMP4 primers generated PCR amplicons of $197 \mathrm{bp}$ the PCR product (197 bp) was digested with HphI. Digestion produced a $197 \mathrm{bp}$ fragment in the A147 allele that lacks the HphI site while the digestion detected $110 \mathrm{bp}$ and $87 \mathrm{bp}$ fragments in the V147 allele having the recognition site.

\section{RESULTS}

We analysed the single-nucleotide polymorphism (SNP) of rs 17563 and difference in the frequency of SNP rs 17563 in cases compared with controls, to estimate the relative risk of genotypes of BMP4T538C on the occurrence of NSCLP using odds ratio and 95\% confidence interval (CI). The gender distribution was similar between groups (Fisher's exact test). Significant differences in genotype distribution and allele polymorphism rs17563 mutations

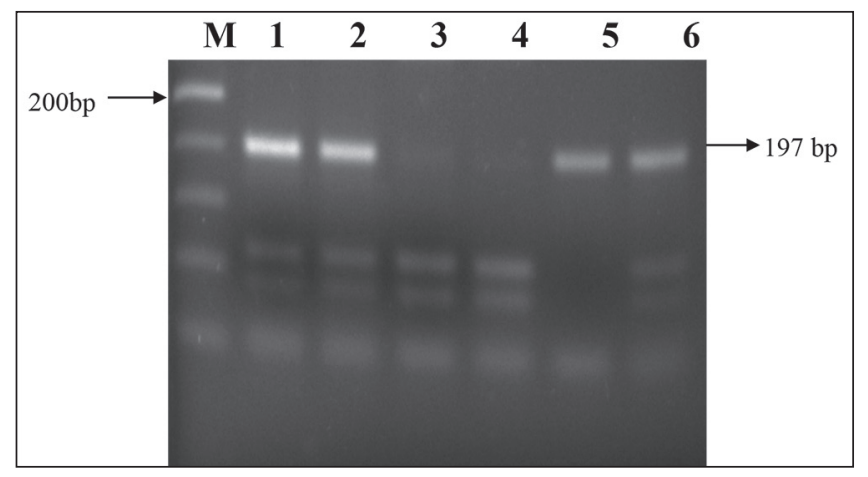

Figure 1: $\mathrm{Hph} /$ restriction fragment length polymorphism. Lane M: Gene Ruler 50 bp DNA Ladder; Lane 1, 2 and 6: 3 bands representing TC allele; Lane 3 and 4: 2 bands representing CC allele; Lane 5: Single band representing allele

Indian Journal of Plastic Surgery May-August 2015 Vol 48 Issue 2 
were found in BMP4 gene in a sample of patients and in a control population. Logistic regression revealed association of CC genotype and CLP susceptibility compared to TT [Table 1] (odds ratio [OR]-5.59 and 95\% $\mathrm{CI}=2.85-10.99)$. A significant association was also observed between $\mathrm{C}$ allele and $\mathrm{CL} \pm P$ compared with $\mathrm{T}$ allele $\left(\chi^{2}=43.89, P<0.05\right)(\mathrm{OR}-4.2 \% \mathrm{CI}=2.75-6.41)$ for BMP4 T >C the frequency of 538C allele was $118 \%$. We can conclude that when haplotypes and cleft were investigated, increased risk of NSCLP was found for homozygous CC and heterozygous TC genotype compared with genotype. These results suggested that one or more SNPs of BMP4 (BMP4T538C) are associated with increased occurrence of NSCLP and confirms the role of polymorphism of BMP4 gene in the aetiology of NSCLP. Thus, there is a significant relationship between SNP and non-syndromic cleft lip with or without palate patients and $P<0.005$.

\section{DISCUSSION}

BMP4, located at $14 \mathrm{q} 22-\mathrm{q} 23$ in humans, is a member of the transforming growth factor-beta superfamily. Have a number of distinct roles in embryonic development, including facial development, by regulating cell proliferation, differentiation, apoptosis and chemotaxis (Hogan, 1996; Ebara and Nakayama, 2002). In particular, the overexpression of BMP4 has been found in the maxillary prominence (Gong and Guo, 2003), one of the regions of prefusion in face development of embryon, which form the lateral parts of the upper lip and the secondary palate (Tapadia et al., 2005). In addition, the presence of a cleft phenotype in BMP4 knockout mice (Cobourne, 2004) or in BMP4 null mutant mice (Liu et al., 2005) reveals the importance of BMP4 during embryonic facial fusion. Based on its role in craniofacial development, as well as evidence from animal experimental studies ${ }^{[21-24]}$ and human linkage studies, ${ }^{[25,26]}$ BMP4 has been considered a promising candidate gene for NSCL/P and intensely

Table 1: Genotype distribution of rs17563 in NSCLP patients and controls and results of logistic regression

\begin{tabular}{lcccccc}
\hline SNP rs17563 & Controls & Cases & $\boldsymbol{X}^{2}$ & $\boldsymbol{P}$ & OR & $\mathbf{9 5 \%} \mathbf{C l}$ \\
\hline Genotype & & & & & & \\
& 32 & 68 & & & & \\
TC & 18 & 13 & 6.527 & 0.011 & 2.94 & $1.29-6.71$ \\
CC & 50 & 19 & 24.98 & 0.000 & 5.59 & $2.85-10.99$ \\
Allele & & & & & & \\
T & 82 & 149 & & & & \\
C & 118 & 51 & 43.59 & 0.00 & 4.2 & $2.75-6.41$ \\
\hline
\end{tabular}

SNP: Single-nucleotide polymorphism; NSCLP: Non-syndromic cleft lip with or without cleft palate; OR: Odds ratio; Cl: Confidence interval

Indian Journal of Plastic Surgery May-August 2015 Vol 48 Issue 2 studied in association studies using case-control ${ }^{[16,17]}$ and case-parent trio designs. ${ }^{[18-20]}$ Expression studies of BMPs and their antagonist Noggin. In the embryonic chicken face has suggested that BMP signals are important for the closure of the upper lip or primary palate. Gain- and loss-of-function experiments showed that BMPs regulate outgrowth and epithelial survival during avian lip fusion. ${ }^{[9]}$ Conditional inactivation of BMP4 in a transgenic mouse line has been found to result in an isolated CL. ${ }^{[27]}$ In view of its role in the regulation of skeletal development including cartilage and bone formation during craniofacial development, ${ }^{[14]}$ Fengfer used Noggin mutant mice as a model for assessing role of BMP4 gene in palatogenesis he found prominent Noggin expression in the palatal epithelium along the anterior-posterior axis during palate development and loss of Noggin leads to overactive BMP signalling that resulting in deregulation of cell proliferation, excessive cell death and change in gene expression leading to formation of palatal cleft, ${ }^{[28]}$ several genome-wide association studies have been conducted across different populations to identify genetic variants of the BMP4 gene, which could be associated with NSCLP in humans. ${ }^{[5,16,29]}$ Was first suggested in a case-control study performed with Chinese children in 2008 by Lin, authors analysed the SNP of rs 17563 and found an increased risk of NSCL/P among carriers of the C allele. ${ }^{[16]} \mathrm{L}$ jianyan, in his hospital-based case-control study in Chile identified the interactions between 538 (T-C) polymorphic site of BMP4 gene and the exposures in pregnancy with NSCLP showed homozygosity for polymorphism (CC) resulted in significantly raised risk compared to TT genotypes, the authors did not find an increased risk for heterozygous TC genotype compared with the TT genotypes. Lin $^{[16]}$ supported the role of BMP4 in NSCLP through their study on 150 unrelated trios showed significant transmission distortion for haplotypes rs1957860-rs762642specially for $\mathrm{C}-\mathrm{T}$ and $\mathrm{T}-\mathrm{T}$, which include the genomic region where the promoter and an enhancer of BMP4 are located. ${ }^{[17]}$ Bings case-control study on Chinese population evaluated BMP4T583C polymorphism resulting in amino acid change VI52A out of genotypes of 184 patients with NSCLP and 205 controls detected using PCR-RFLP strategy the 538C allele carriers were associated with significantly increased risk of NSCL/P as compared to no carriers,. Suazo in his case-control study on Chilean population confirmed the possible mutation of BMP4 promoters BMP4.1 and BMP4.2 on three novel variants of BMP41 (C-5514G >A, C-5365C > T and 5049C > T concluded that risk variants detected could potentially alter BMP4 promoter activity in NSCLP. ${ }^{[1]}$ A missense 
and nonsense mutations were found in BMP4 gene in a sample of patients from different genetic background mutations were not found in a control population by Suazo et al. ${ }^{[18,29]}$ Searched for NSCLP risk variants within the two BMP4 promoters by direct sequencing in a 167 Chilean NSCLP cases and 336 controls and found three novel variants considered as cleft risk factors, as they are not present in controls. Lately, Chen et al. ${ }^{[19]}$ provided further evidence of an association between BMP4 gene and NSCLP in Asian and Maryland trios. These studies point that BMP4 gene polymorphisms clearly have different effects in different populations, Arauja did a case-control study in a Brazilian population and found a different results of the $538 \mathrm{C}$ allele having a protective effect on NSCLP, ${ }^{[16]}$ our study showed homozygosity for polymorphism (CC) resulted in significantly increased susceptibility compared to TT genotypes, also association was found for heterozygous genotype TC compared with the TT genotypes. Confirming the association between polymorphism of rs 17563 of BMP4 gene with NSCLP in Indian population, this result was in accordance with findings of Lin and Suzuki and Jin and against the findings of Arauja study in a Brazilian population and Antunes, ${ }^{[16]}$ this study support the hypothesis that this polymorphism might play a definite role in different ethnicity. However, NSCLP is a multifactorial disease where multiple aetiologic factors, both genetic and environmental could either act solely or in combination with different levels of cell to cell interactions or during different signalling pathways, so it is very hard to declare a single variant of a particular gene to be responsible for NSCLP-based on gene association studies and several other restriction segments of different genes are also studied individually or in combination with environmental factors thus there is a need for further research in this area in different population to be elucidated.

\section{CONCLUSION}

Cleft lip and palate are common congenital anomalies which pose considerable and often lifelong taboo and suffering for the patient as well as the family. Despite the complete rehabilitation of the defect that is possible now, the repeated number of hospital visits and surgeries can leave the patient and the caretaker burdened and depressed. Relentless research in evaluating the different speculated stoppable aetiologic factors is growing on in this purview but still there is no definite answer to the aetiology of the defects. The identification of the modifiable risk factors for cleft lip and palate is the first step towards the primary prevention and recognition of risk factor is the wanting for further genetic counselling in the prevention of such congenital anomalies. Research was done in different ethnic groups and geographic locations can help us clearly be in a better position to find a solution to this global problem and this should eventually result in improved prevention. The results of our study suggest an association of the SNP of BMP4 gene among carriers of the $\mathrm{C}$ allele and increased risk for NSCLP in an Indian Population. Further studies on this aspect can scale large heights in preventive strategies for NSCLP that may soon become a reality.

\section{Acknowledgement}

I sincerely acknowledge the support extended by the head of the Craniofacial Rehabilitation Centres, the patients and parents.

\section{Financial support and sponsorship \\ Nil.}

\section{Conflicts of interest}

There are no conflicts of interest.

\section{REFERENCES}

1. Kaartinen V, Cui XM, Heisterkamp N, Groffen J, Shuler CF. Transforming growth factor-beta3 regulates transdifferentiation of medial edge epithelium during palatal fusion and associated degradation of the basement membrane. Dev Dyn 1997;209:255-60.

2. Martínez-Alvarez C, Tudela C, Pérez-Miguelsanz J, O'Kane S, Puerta J, Ferguson MW. Medial edge epithelial cell fate during palatal fusion. Dev Biol 2000;220:343-57.

3. Meng L, Bian Z, Torensma R, Von den Hoff JW. Biological mechanisms in palatogenesis and cleft palate. J Dent Res 2009;88:22-33.

4. Wehby $\mathrm{GL}$, Cassell $\mathrm{CH}$. The impact of orofacial clefts on quality of life and healthcare use and costs. Oral Dis 2010;16:3-10.

5. Marazita ML, Lidral AC, Murray JC, Field LL, Maher BS, Goldstein McHenry T, et al. Genome scan, fine-mapping, and candidate gene analysis of non-syndromic cleft lip with or without cleft palate reveals phenotype-specific differences in linkage and association results. Hum Hered 2009;68:151-70.

6. Birnbaum S, Ludwig KU, Reutter H, Herms S, Steffens M, Rubini M, et al. Key susceptibility locus for nonsyndromic cleft lip with or without cleft palate on chromosome 8q24. Nat Genet 2009;41:473-7.

7. Grant SF, Wang K, Zhang H, Glaberson W, Annaiah K, Kim CE, et al. A genome-wide association study identifies a locus for nonsyndromic cleft lip with or without cleft palate on 8q24. J Pediatr 2009;155:909-13.

8. Mangold E, Ludwig KU, Birnbaum S, Baluardo C, Ferrian M, Herms S, et al. Genome-wide association study identifies two susceptibility loci for nonsyndromic cleft lip with or without cleft palate. Nat Genet 2010;42:24-6.

9. Nie X, Luukko K, Kettunen P. BMP signalling in craniofacial development. Int J Dev Biol 2006;50:511-21.

10. Gong SG, Guo C. Bmp4 gene is expressed at the putative site of fusion in the midfacial region. Differentiation 2003;71:228-36.

Indian Journal of Plastic Surgery May-August 2015 Vol 48 Issue 2 
11. Mangino M, Torrente I, De Luca A, Sanchez O, Dallapiccola B, Novelli G. A single-nucleotide polymorphism in the human bone morphogenetic protein-4 (BMP 4) gene. J Hum Genet 1999;44:76-7.

12. Zhang Z, Song $Y$, Zhao X, Zhang X, Fermin C, Chen Y. Rescue of cleft palate in Msx1-deficient mice by transgenic Bmp4 reveals a network of BMP and SHH signaling in the regulation of mammalian palatogenesis. Development 2002;129:4135-46.

13. Wall NA, Hogan BL. Expression of bone morphogenetic protein-4 (BMP-4), bone morphogenetic protein-7 (BMP-7), fibroblast growth factor-8 (FGF-8) and sonic hedge hog (SHH) during branchial arch development in the chick. Mech Dev 1995;53:383-92.

14. Liu W, Sun X, Braut A, Mishina $Y$, Behringer RR, Mina M, et al. Distinct functions for Bmp signaling in lip and palate fusion in mice. Development 2005;132:1453-61.

15. Thomason HA, Dixon MJ, Dixon J. Facial clefting in Tp63 deficient mice results from altered Bmp4, Fgf8 and $\mathrm{SHH}$ signaling. Dev Biol 2008;321:273-82.

16. Lin JY, Chen YJ, Huang YL, Tang GP, Zhang L, Deng B, et al. Association of bone morphogenetic protein 4 gene polymorphisms with nonsyndromic cleft lip with or without cleft palate in Chinese children. DNA Cell Biol 2008;27:601-5.

17. Suzuki S, Marazita ML, Cooper ME, Miwa N, Hing A, Jugessur A, et al. Mutations in BMP4 are associated with subepithelial, microform, and overt cleft lip. Am J Hum Genet 2009;84:406-11.

18. Suazo J, Tapia JC, Santos JL, Castro VG, Colombo A, Blanco R. Risk variants in BMP4 promoters for nonsyndromic cleft lip/palate in a Chilean population. BMC Med Genet 2011;12:163.

19. Chen Q, Wang H, Hetmanski JB, Zhang T, Ruczinski I, Schwender $\mathrm{H}$, et al. BMP4 was associated with NSCL/P in an Asian population. PLoS One 2012;7:e35347.
20. Barlow AJ, Francis-West PH. Ectopic application of recombinant BMP-2 and BMP-4 can change patterning of developing chick facial primordia. Development 1997;124:391-8.

21. Mossey P, Castillia E. Global Registry and Database on Craniofacial Anomalies. Geneva: World Health Organization; 2003.

22. Ashique $\mathrm{AM}, \mathrm{Fu} \mathrm{K}$, Richman JM. Endogenous bone morphogenetic proteins regulate outgrowth and epithelial survival during avian lip fusion. Development 2002;129:4647-60.

23. Sathyaprasad S, Sharma SM, Shetty V. BMP4 gene and pathophysiology of cleft lip and palate. Res Rev J Dent Sci 2014;2:10

24. Wan M, Cao X. BMP signaling in skeletal development. Biochem Biophys Res Commun 2005;328:651-7.

25. He F, Xiong W, Wang Y, Matsui M, Yu X, Chai Y, et al. Modulation of BMP signaling by Noggin is required for the maintenance of palatal epithelial integrity during palatogenesis. Dev Biol 2010;347:109-21.

26. Araújo TK, Simioni M, Félix TM, de Souza LT, Fontes Mí, Monlleó IL, et al. Preliminary analysis of the nonsynonymous polymorphism rs17563 in BMP4 gene in brazilian population suggests protection for nonsyndromic cleft lip and palate. Plast Surg Int 2012;2012:247104.

27. Paiva KB, Silva-Valenzuela MD, Massironi SM, Ko GM, Siqueira FM, Nunes FD. Differential SHH, Bmp and Wnt gene expressions during craniofacial development in mice. Acta Histochem 2010;112:508-17.

28. Marazita ML, Murray JC, Lidral AC, Arcos-Burgos M, Cooper ME, Goldstein $\mathrm{T}$, et al. Meta-analysis of 13 genome scans reveals multiple cleft lip/palate genes with novel loci on 9q21 and 2q32-35. Am J Hum Genet 2004;75:161-73.

29. Antunes LS, Küchler EC, Tannure PN, Costa MC, Gouvêa CV, Olej B, et al. BMP4 polymorphism is associated with nonsyndromic oral cleft in a Brazilian population. Cleft Palate Craniofac J 2013;50:633-8. 